\title{
NUTRIENT RECYCLING OF SORGHUM STRAW AND SOIL BIOLOGICAL ATTRIBUTES IN EASTERN AMAZON
}

\author{
Reciclagem de nutrientes da palhada de sorgo e atributos \\ biológicos do solo na Amazônia Oriental \\ Patrícia Ribeiro Maia ${ }^{1}$, Antonio Rodrigues Fernandes², Vânia Silva Melo', \\ Elaine Rodrigues Santos ${ }^{1}$, Gisele Barata da Silva ${ }^{1}$
}

\begin{abstract}
The microbial biomass and activity are biological indicators sensitive to environmental changes caused by agricultural use and can provide important information for the planning of adequate land use. The objective of this research was to evaluate the nutrient recycling, persistence, and biological attributes of sorghum straw in Oxisol as a function of soil management systems. The experiment was carried out at the Federal Rural University of Amazonia in randomized block design with $3 \times 2$ factorial and four replicates. Three sorghum hybrids and two soil management systems were the factors used to assess straw decomposition. In order to evaluate the biological attributes, a $2 \times 2$ factorial experiment with four replicates was carried out using two soil management systems and two sampling dates. Total organic carbon (TOC), carbon in the soil microbial biomass (C-SMB), C-SMB/TOC ratio, basal respiration and metabolic quotient $\left(q \mathrm{CO}_{2}\right)$ were investigated. The Qualimax hybrid presented the highest $\mathrm{C} / \mathrm{N}$ ratio (55) and longer straw persistence in soil after 120 days of management (35\%). The highest TOC, C-SMB, C-SMB/TOC ratio, and basal respiration and the smallest $q \mathrm{CO}_{2}$ were observed during the rainy season and in the no-till system.
\end{abstract}

Index terms: Microbial biomass, $\mathrm{C} / \mathrm{N}$ ratio, Oxisol.

\section{RESUMO}

A atividade e biomassa microbiana são indicadores biológicos sensíveis a alterações ambientais decorrentes do uso agrícola, podendo fornecer informações importantes para o uso adequado do solo. Objetivou-se, com este trabalho, avaliar a ciclagem de nutrientes, atributos biológicos e a persistência da palhada de sorgo em um Latossolo Amarelo distrófico, em função de sistemas de manejo do solo. O experimento foi realizado na Universidade Federal Rural da Amazônia, em um delineamento em blocos casualizados, com fatorial 3 x 2 e quatro repetições. Os fatores foram: três híbridos de sorgo e dois sistemas de manejo do solo, para avaliar a decomposição da palhada. Para avaliar os atributos biológicos, um experimento com fatorial 2 × 2, foram feitas, com quatro repetições, sendo dois fatoresos sistemas de manejo do solo e os outros dois as datas de amostragem. O carbono orgânico total (COT), o carbono da biomassa microbiana do solo (CBM), a relação CBM/ COT, a respiração basal e o quociente metabólico foram analisados. O híbrido Qualimax obteve a maior relação C/N (55) e maior persistência da palhada no solo, após 120 dias de manejo (35\%). No período mais chuvoso e no sistema de plantio direto, observaram-se maiores valores de COT, CBM, relação CBM/COT, respiração basal e menor $q \mathrm{CO}_{2}$.

Termos para indexação: Biomassa microbiana, relação C/N, Latossolo.

(Received in june 23, 2012 and approved in august 29, 2012)

\section{INTRODUCTION}

The Amazonian biome in Brazil has been intensely impacted by human use. The no-till soil management system can help to protect the soil biological resources because it allows for the crop straw to stay on soil surface longer, increasing soil organic matter. Sorghum plants can be used as cover crop in the no-till system because they present great dry mass production and regrowth capacity, and high $\mathrm{C} / \mathrm{N}$ ratio and nutrient reserve (TORRES; PEREIRA, 2008).

Soil biological attributes such as microbial biomass, basal respiration and metabolic quotient are important soil quality indicators (KASCHUC; ALBERTON; HUNGRIA, 2011) and are very sensitive to changes due to soil management, being used for the monitoring of environmental changes resulting from agricultural use. The microbial biomass activity is related to the dynamic of soil organic matter, signaling changes in both short and long time periods (ARAÚJO; SANTOS; MONTEIRO, 2008). The microbial biomass provides a more efficient use of resources in the ecosystem: less $\mathrm{CO}_{2}$ is lost by respiration and a higher proportion of $\mathrm{C}$ is incorporated in the microbial tissues (FOLLET; SCHIMEL, 1989), which result in decreased metabolic quotient $\left(q \mathrm{CO}_{2}\right)$.

1Universidade Federal Rural da Amazônia/Ufra - Instituto de Ciências Agrárias/ICA - Belém - PA - Brasil

2Universidade Federal Rural da Amazônia/Ufra - Instituto de Ciências Agrárias/ICA - Cx.P. 917 - 66077-901 - Belém - PA - Brasil antonio.r.fernandes@pq.cnpq.br

Ciênc. agrotec., Lavras, v. 36, n. 5, p. 518-525, set./out., 2012 
Soil respiration is sensitive to soil moisture during seasonal fluctuations. The metabolic quotient $\left(q \mathrm{CO}_{2}\right)$ is another parameter that has been useful in monitoring the effects of environmental changes in soil microbial communities (CARNEIRO et al., 2009). Conventional soil management practices have led to soil quality loss and CSMB and $q \mathrm{CO}_{2}$ are sensitive to these alterations (PÔRTO et al., 2009).

Plant cover species produce different effects on the biological and chemical attributes of the soil (CARNEIRO et al., 2008) and, despite its importance, little is known about the influence of sorghum straw on the microbial biomass activity and soil nutrients cycling, especially in Amazonian soils.

The purpose of this study was to evaluate the nutrient recycling, decomposition and half-life of sorghum residues, and the biological attributes of soil as a function of Oxisol management systems during different periods in eastern Amazonia.

\section{MATERIALS AND METHODS}

The research was developed in an experimental area at the Federal Rural University of Amazonia, State of Para, Brazil (48 26'28" W; 01 27' 9" S; 13 m above sea level), between 2008 and 2009. Before the experimental period, the area was used for several crops during the past 30 years. The soil was classified as Dystrophic Yellow Latosol (Oxisol) (EMPRESA BRASILEIRA DE PESQUISA AGROPECUÁRIA-EMBRAPA, 2006), with medium clay content and 3\% mean declivity. The climate was classified as $A f i$ in the Köppen classification system with average temperature of $26^{\circ} \mathrm{C}$ and $2,754.4 \mathrm{~mm}$ of annual rainfall. The rainy season is from December to May (77\% of the annual rainfall) and the dry (not as rainy) season from June to November (CÂNDIDO et al., 2007) (Figure 1).

Prior to experiment establishment, 20 sub-samples were collected and mixed to produce two composite samples, at 0.0 to $0.1 \mathrm{~m}$ and 0.1 to $0.2 \mathrm{~m}$ depths, processed in accordance with Embrapa (1997) (Table 1).

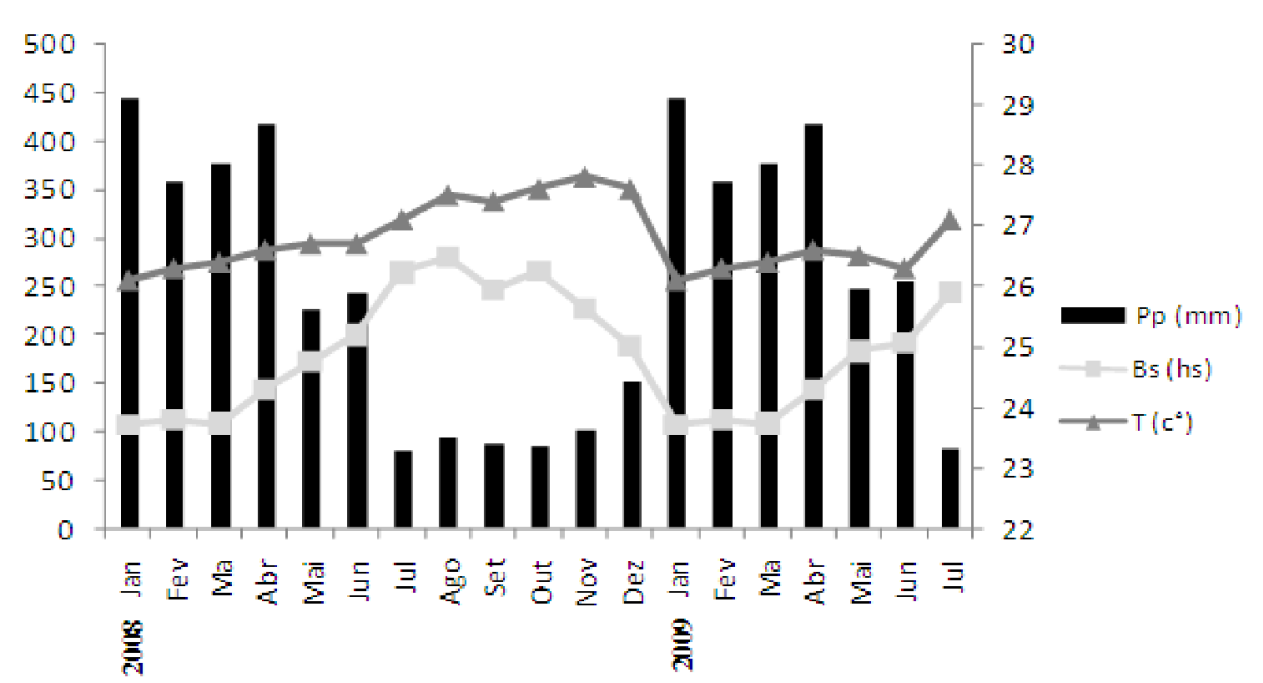

Figure 1 - Monthly averages of rainfall $(\mathrm{Pp})$, sunshine $(\mathrm{N})$ and air temperature $(\mathrm{T})$ during the experimental period (2008-2009).

Table 1 - Chemical and physical properties of Oxisol, medium textured (layers 0-0.1 and 0.1-0.2 m), prior to experiment.

\begin{tabular}{ccccccccccccc}
\hline Depth & $\mathrm{pH}$ & $\mathrm{P}$ & $\mathrm{K}$ & $\mathrm{Ca}$ & $\mathrm{Mg}$ & $\mathrm{H}+\mathrm{Al}$ & $\mathrm{V}$ & $\mathrm{OM}$ & Coarse sand & Fine sand & Silt & Clay \\
\hline $\mathrm{m}$ & $\mathrm{H}_{2} \mathrm{O}$ & $\mathrm{mg} \mathrm{dm}^{-3}$ & \multicolumn{6}{c}{$\ldots \ldots . \mathrm{mmol}_{\mathrm{c}} \mathrm{dm}^{-3} \ldots \ldots$} & $\%$ & & $\ldots \ldots \ldots \ldots \ldots . . . \mathrm{g} \mathrm{kg}^{-1} \ldots \ldots \ldots \ldots \ldots \ldots \ldots . . . \ldots \ldots \ldots \ldots$ & \\
$0.0-0.1$ & 4.8 & 9.7 & 0.4 & 2.0 & 1.1 & 4.5 & 8.9 & 14.0 & 477 & 336 & 91 & 96 \\
$0.1-0.2$ & 4.6 & 6.2 & 0.2 & 1.7 & 0.9 & 4.4 & 8.5 & 12.4 & 472 & 337 & 95 & 97 \\
\hline
\end{tabular}

$\mathrm{V}=$ percentage of soil base saturation; $\mathrm{OM}=$ organic matter. 
A statistical randomized block design with $3 \times 2$ factorial and four replicates was used for straw persistence. Three sorghum hybrids (Sorghum bicolor (L.) Moench) hybrids (Volumax, AG 2005E and Qualimax) and two soil management systems (conventional tillage CT, and no-till - NT) were used to evaluate straw decomposition.

In order to evaluate the biological attributes, a $2 \times 2$ factorial experiment with four replicates was carried out using two soil management systems and two sampling dates.

Volumax is a commercial sorghum hybrid for forage production, AG 2005E is used both for forage and grain production and Qualimax is utilized for grain production.

The experimental area was cleaned and weeds and plant residue were incorporated to soil through harrowing in the conventional tillage (CT) system. In the no-Till (NT) system, weeds were sprayed with glyphosate $\left(3 \mathrm{~L} \mathrm{ha}^{-1}\right)$. The field was split into $8 \mathrm{~m}^{2}$ plots $(2 \times 4 \mathrm{~m})$ and four lines of plants were sown, with $0.5 \mathrm{~m}$ interval both between plants and lines. Liming was performed with $2.5 \mathrm{t} \mathrm{ha}^{-1}$ dolomitic lime (ECCE 75\%) 30 days before sowing, aiming at $60 \%$ base saturation. Lime was spread over the weed residue in the NT system and plowed in the CT system. Nitrogen $\left(200 \mathrm{~kg} \mathrm{ha}^{-1}\right)$ fertilization was divided in 50\% at sowing (ammonium sulphate) and 50\% (urea) when the sorghum plants presented the fourth leaf completely expanded. Phosphate was applied at sowing $\left(50 \mathrm{~kg} \mathrm{ha}^{-1}\right.$ of $\mathrm{P}_{2} \mathrm{O}_{5}$ ratio) as a triple superphosphate.

Seeds were sown at 15 seeds per meter in January 2008. After sprouting, stands were thinned until the design of one plant every $0.5 \mathrm{~m}$ was achieved. Sorghum buds were first cut after 85 days. Only the two central rows were considered for evaluation, with $0.3 \mathrm{~m}$ at the end of each row and peripheral lines considered as borders.

For estimation of the persistence time of sorghum straw in soil, a square wooden frame with $0.25 \mathrm{~m}^{2}$ was used to collect, at random, the straw samples from two spots within each plot, one day after cutting, as suggested by Stott et al. (1990). The material sampled was dried in oven with air stream, at $65^{\circ} \mathrm{C}$, until constant mass. After weighing, samples were put in nylon screen bags with $1 \mathrm{~mm}$ apertures, $0.2 \times 0.2 \mathrm{~m}$ dimension, and returned to their original plots. The weighing procedure was repeated at $30,60,90$ and 120 days after cutting (DAC).

The amount of nutrients accumulated and remaining in the straw was determined by multiplying the amount of dry matter by the nutrient content of the waste vegetable shoots. With these values, it was possible to calculate the levels of $\mathrm{N}, \mathrm{P}$ and $\mathrm{K}$ remaining in the straw residue on the ground at 30, 60, 90 and 120 days after management (DAM).

An asymptotic model was adjusted for each sample, as defined by Wieder and Lang (1982), according to the following equation: $\mathrm{Nr}$; $\mathrm{Pr}$ and $\mathrm{Kr}=\mathrm{Ae}-\mathrm{kt}+(100-\mathrm{A})$, where $\mathrm{Nr}$; $\mathrm{Pr}$ and $\mathrm{Kr}$ are values of N, P and $\mathrm{K}$ residuals (\% of initial quantity), respectively, in time $t$; $A$ is the initial quantity of $\mathrm{N}, \mathrm{P}$ or $\mathrm{K}$ (\% of initial quantity) contained in labile fraction; $(100-\mathrm{A})$ is the $\mathrm{N}, \mathrm{P}$ or $\mathrm{K}$ (\% of initial quantity) contained in fraction more difficult to mineralize; and $\mathrm{k}$ is a constant liberation rate of $\mathrm{N}, \mathrm{P}$ and $\mathrm{K}$ of fraction A. Based on the constant values of liberation for N, P and $\mathrm{K}$ of A fraction, half-life $\left(\mathrm{t}_{1 / 2}=0,693 / \mathrm{k}\right)$ was calculated according to Paul and Clark (1996). Half-life $\left(\mathrm{t}_{1 / 2}\right)$ is the time necessary for the liberation of $50 \%$ of $\mathrm{N}, \mathrm{P}$ and $\mathrm{K}$ of that fraction.

Aboveground plants were sampled at full flowering and then dried in oven. Organic carbon was measured by the Walkley Black (EMBRAPA, 1997) method, while nitrogen was measured by the semi-micro Kjeldahl method. These results were used to calculate the $\mathrm{C} / \mathrm{N}$ ratio of the aboveground plant.

Soil samples were taken in the dry (not as rainy) season (on December 2, 2008) and in the rainy season (on April 15, 2009). Five soil samples were taken from each plot at 0.00-0.05 m depth in $0.10 \mathrm{~m}$-deep micro pits. Samples were passed through a $2 \mathrm{~mm}$ sieve; root fragments were discarded and the remaining material was kept in polyethylene bags under refrigeration.

The C-SMB was determined according to Vance; Brookes and Jenkinson (1987). Soil basal respiration was estimated using an adaptation of the Jenkinson and Powlson (1976) method and the samples were incubated for 10 days in a flask with $\mathrm{NaOH}$ for $\mathrm{CO}_{2}$ capture.

The metabolic coefficient $\left(q \mathrm{CO}_{2}\right)$ was determined as proposed by Anderson and Domsch (1993). The metabolic quotient $\left(q \mathrm{CO}_{2}=\mathrm{RBS} / \mathrm{C}-\mathrm{SMB}\right)$ was calculated to estimate the efficiency of microbes in substrate usage.

Results were analyzed using analysis of variance and averages were compared by Tukey test at 5\% probability, using Sisvar statistical software (FERREIRA, 2011).

\section{RESULTS AND DISCUSSION}

The persistence of straw was influenced only by the hybrids. At the first evaluation (30 days after phytomass management - DAM), the straw persistence 
did not vary between the hybrids (Table 2). After 60 days, the Qualimax hybrid presented the greatest straw persistence, and Volumax and AG 2005E hybrids did not differ from each other. At the last evaluation (120 days), Qualimax showed 35\% of non-decomposed straw (Table 2 ), which is related to its higher $\mathrm{C} / \mathrm{N}$ ratio (Table 3 ). However, genetic factors such as lignin concentration may also have influenced this result. High levels of lignin and $\mathrm{C} / \mathrm{N}$ ratio imply smaller degradation, which, in turn, maintains straw on soil surface for a longer time (METAY et al., 2007). This is important because straw on the surface protects the soil and benefits its chemical, physical and biological characteristics (TORRES; PEREIRA, 2008).

Table 2 - Straw persistence percentage of the three sorghum hybrids in Oxisol for the two management systems.

\begin{tabular}{cccc}
\hline DAM & Volumax & AG 2005-E & Qualimax \\
\hline \multicolumn{4}{c}{ Conventional till } \\
30 & $65 \mathrm{a}$ & $63 \mathrm{a}$ & $66 \mathrm{a}$ \\
60 & $42 \mathrm{~b}$ & $40 \mathrm{~b}$ & $49 \mathrm{a}$ \\
90 & $36 \mathrm{~b}$ & $32 \mathrm{~b}$ & $44 \mathrm{a}$ \\
120 & $26 \mathrm{~b}$ & $23 \mathrm{~b}$ & $39 \mathrm{a}$ \\
\multicolumn{4}{c}{ No-till } \\
30 & $61 \mathrm{a}$ & $63 \mathrm{a}$ & $63 \mathrm{a}$ \\
60 & $42 \mathrm{~b}$ & $42 \mathrm{~b}$ & $46 \mathrm{a}$ \\
90 & $31 \mathrm{~b}$ & $30 \mathrm{~b}$ & $40 \mathrm{a}$ \\
120 & $25 \mathrm{~b}$ & $24 \mathrm{~b}$ & $38 \mathrm{a}$ \\
CV $(\%)$ & 11.25 & 16.04 & 9.73 \\
\hline
\end{tabular}

$\mathrm{DAM}=$ days after management. Different letters on rows imply significant statistical difference by the Tukey test at 5\% probability.

Table 3 - Carbon $(\mathrm{C})$ and Nitrogen $(\mathrm{N})$ concentrations in leaf tissue and $\mathrm{C} / \mathrm{N}$ ratio of the three sorghum hybrids, cropped in Oxisol.

\begin{tabular}{|c|c|c|c|}
\hline & Carbon & Nitrogen & $\mathrm{C} / \mathrm{N}$ relation \\
\hline & \multicolumn{3}{|c|}{$\ldots \ldots \ldots \ldots \ldots \ldots . . . \mathrm{g} \mathrm{kg}^{-1}$} \\
\hline Volumax & $450.5 \mathrm{a}$ & $12.8 \mathrm{a}$ & $35.2 b$ \\
\hline AG 2005-E & $451.2 \mathrm{a}$ & $12.6 \mathrm{a}$ & $35.8 \mathrm{~b}$ \\
\hline Qualimax & $452.0 \mathrm{a}$ & $8.2 b$ & $55.0 \mathrm{a}$ \\
\hline $\mathrm{CV}(\%)$ & 12.22 & 15.92 & 12.48 \\
\hline
\end{tabular}

Different letters on columns imply significant statistical difference by the Tukey test at $5 \%$ probability.
The $\mathrm{C}$ concentration in sorghum leaf tissue did not differ between the hybrids. The smallest concentration of $\mathrm{N}$ was found in the Qualimax hybrid $\left(8.2 \mathrm{~g} \mathrm{~kg}^{-1}\right)$ (Table 3). The $\mathrm{N}$ concentration in sorghum 90 days after sowing was $12.92 \mathrm{~g} \mathrm{~kg}^{-1}$, as reported by Silva et al. (2007), which is similar to the concentrations measured in the present study for AG 2005-E and Volumax hybrids. AG 2005-e and Volumax hybrids showed smaller C/N ratio than the Qualimax hybrid, and did not differ from one another (Table 3 ). The highest $\mathrm{C} / \mathrm{N}$ ratio (50/1), which was observed for the Qualimax hybrid, may have contributed, as expected, to the smallest rate of straw decomposition (METAY et al., 2007). The C/N ratios found in the present study were different between the hybrids tested; this is in accordance with the results reported by Mateus; Crusciol and Negrisoli (2004), who observed that this ratio was directly related to the $\mathrm{N}$ levels of crops. Ratios as high as 73.19 were observed for sorghum crops by Silva et al. (2007).

The total organic carbon (TOC) ranged from 11.6 to $15.4 \mathrm{~g}$, being higher in the NT (no-till) system than in the CT (conventional till) system (Table 4). In the NT system, the input of organic material on the soil surface layer allows for slower decomposition, increasing the TOC. Higher TOC values were also reported by Carneiro et al. (2009) when comparing the effect of management systems on soil biological properties.

Table 4 - Total organic carbon (TOC), carbon in microbial biomass (C-SMB), C-SMB/TOC ratio, basal respiration (BR) and metabolic quotient $\left(q \mathrm{CO}_{2}\right)$ as a function of sampling season.

\begin{tabular}{|c|c|c|}
\hline $\begin{array}{l}\text { Biological } \\
\text { attributes }\end{array}$ & $\begin{array}{c}\text { less rainy } \\
\text { season }\end{array}$ & $\begin{array}{c}\text { rainy } \\
\text { season }\end{array}$ \\
\hline TOC ( $\mathrm{g} \mathrm{kg}^{-1}$ soil $)$ & $11.6 \mathrm{~b}$ & $15.3 \mathrm{a}$ \\
\hline 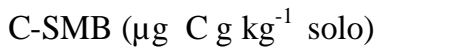 & $245.3 b$ & $256.7 \mathrm{a}$ \\
\hline Relation C-SMB/TOC & $1.7 \mathrm{~b}$ & $2.1 \mathrm{a}$ \\
\hline $\operatorname{RBS}\left(\mathrm{mg} \mathrm{C}-\mathrm{CO}_{2} \mathrm{~g}^{-1}\right.$ solo $\mathrm{h}^{-1}$ ) & $6.5 b$ & $7.4 \mathrm{a}$ \\
\hline$q \mathrm{CO}_{2}\left(\mathrm{mg} \mathrm{C}-\mathrm{CO}_{2} \mathrm{~g}^{-1} \mathrm{C}-\mathrm{mic} \mathrm{h}^{-1}\right)$ & $0.03 \mathrm{a}$ & $0.02 \mathrm{~b}$ \\
\hline $\mathrm{CV}(\%)$ & 7.81 & 11.49 \\
\hline
\end{tabular}

Different letters on rows contrast sampling seasons by the Tukey test at $5 \%$ probability.

Carbon in microbial biomass (C-SMB) was also greater in the NT system than in the CT system (Table 4). This is probably related to the crop residue on soil surface ( 0 to $0.05 \mathrm{~m}$ ), supporting active biomass. These results are in agreement with Rangel and Silva (2007), who evaluated 
biological properties in several management systems and observed that the more conservative ones supported greater C-SMB concentrations. Positive effects of organic manure during the first year were reported by Černý et al. (2008). These results suggested that the maintenance of organic matter implies higher values of C-SMB. The C-SMB fluctuation observed during the two sampling seasons is related to variation in moisture, temperature and rainfall on the activity of soil microbe population (NARDOTO; BUSTAMENTE, 2003).

The greatest C-SMB and TOC ratios were observed during the rainy season in the NT system (Table 4). These results are in agreement with those found by Silva et al. (2007), that is, $2.3 \%$ for CT and $2.5 \%$ for NT. The smallest C-SMB/TOC ratio, for the rainy season, was $1.7 \%$ and was related to the greater amount of nondecomposed straw and rainfall fluctuation at the first sampling. In rice crops, Zang et al. (2009) observed C$\mathrm{SMB} / \mathrm{TOC}$ ratio between $5 \%$ and $9 \%$ as a function of growing stage, with the highest value found in plots where organic fertilizer had been used.

Basal respiration was greater in the NT system during the rainy season (Table 4), probably due to the greater amount of organic matter, richer in labile substances, in this system (CARNEIRO et al., 2009). Greater basal respiration during the rainy season can be related to greater soil moisture, which increases microbial development. The basal respiration and metabolic quotient $\left(q \mathrm{CO}_{2}\right)$ are usually sensitive to seasonal fluctuations, including soil moisture (PORTO et al., 2009).

$q \mathrm{CO}_{2}$ was smaller in the NT system; this fact may be related to the greater nutrient availability, better aeration and greater moisture found in this management system, although the $q \mathrm{CO}_{2}$ values were considered small in both systems (CT and NT) (Table 4). Similar results were reported by Carneiro et al. (2009) during the assessment of ten management systems. A $q \mathrm{CO}_{2}$ of $0.02 \mathrm{mg} \mathrm{C}-\mathrm{CO}_{2} \mathrm{~g}-$ ${ }^{1} \mathrm{ha}^{-1} \mathrm{~g}^{-1}$ of soil was observed in sorghum crops managed with no-till system. In addition, Xavier et al. (2006) found smaller values of $q \mathrm{CO}_{2}$ in NT than in CT.

The smallest $q \mathrm{CO}_{2}$ was identified during the rainy season (Table 4) probably due to an increase in soil moisture during this period. The small $q \mathrm{CO}_{2}$ values found in the present research relate to the efficiency of the microbial population of this soil to use organic substrates, since the greater the amount of $\mathrm{C}$ being incorporated into the microbial biomass, the smaller the amount $\mathrm{C}$ lost through respiration.
Lesser microbial activity was observed in the dry (less rainy) season (June to November) than in the rainy period (Table 4). Periods with lower amounts of rainfall or atypical periods with prolonged drought have been observed in the world due to the effects caused by the El Nino and La Nina phenomena. Such effects cause losses to agriculture once they bring on an imbalance in the biology and chemistry of soils (ZANG et al., 2009). All soil biological attributes analyzed in this study (Table 4) were susceptible to the sampling periods (rainy or dry seasons).

Initially, the Qualimax hybrid showed lower accumulation of $\mathrm{N}$ in both soil management systems (Table 5), this feature may be related to the genetics of the hybrid. In the last sampling, the crop residues of sorghum in the CT system showed higher $\mathrm{N}$ content in straw for the Volumax hybrid. In the NT system, it was found that the Qualimax hybrid presented lower the accumulations of $\mathrm{N}$ in straw for both the first and last samples. The P relation to the accumulation of the AG2005E hybrid stands out for having the first and last samplings and the two soil management systems under the accumulation of $\mathrm{P}$ (Table 5).

Potassium was the nutrient accumulated in larger quantities, reaching $204.2 \mathrm{~kg} \mathrm{ha}^{-1}$ in the Qualimax hybrid under no-tillage (Table 5). The $\mathrm{N}$ relation to the accumulation of the AG2005-E hybrid stands out for having the first and last samplings and the two soil management systems under the accumulation of $\mathrm{P}$ (Table 5). Boer et al. (2007) also observed a higher accumulation of $\mathrm{P}$ with respect to $\mathrm{N}$ and $\mathrm{K}$ in plant tissue.

The sorghum hybrids showed half-lives $\left(\mathrm{T}_{1 / 2}\right)$ of so many different hybrids among management systems. These results are due, probably, to the different relations $\mathrm{C} / \mathrm{N}$ hybrids and the differences in biological attributes of the two management systems studied (Table 5). The values of $\mathrm{T}_{1 / 2}$ with respect to $\mathrm{N}$ and $\mathrm{P}$ were lower than the ones found by Torres et al. (2008) when evaluating sorghum crop at 155 and 198 days after sowing. The lower values of $T_{1 / 2}$ observed in this study can be justified by high rainfall and temperature during the experimental period (Table 1).

$\mathrm{K}$ was the nutrient more rapidly released (between 29 to 34 days) in residues of sorghum hybrids. Similar results were observed by Teixeira et al. (2011), who observed quick release of $\mathrm{K}$ (95\% in approximately 30 days) when working with the decomposition of millet and sorghum cover crops. 
Table 5 - Accumulated and remaining amounts of N, P and K in the straw of sorghum hybrids at 0, 30, 60, 90 and 120 days after management (DAM), in a Yellow Latosol.

\begin{tabular}{|c|c|c|c|c|c|c|}
\hline \multicolumn{7}{|c|}{ Conventional till } \\
\hline DAM & 0 & 30 & 60 & 90 & 120 & $\mathrm{t}_{1 / 2(\text { days })}$ \\
\hline \multicolumn{7}{|c|}{------------N (kg ha $\left.{ }^{-1}\right)--$} \\
\hline Volumax & $132.0 \mathrm{a}$ & $85.8 \mathrm{a}$ & $55.5 \mathrm{a}$ & $47.5 \mathrm{a}$ & $47.5 \mathrm{a}$ & $50 \mathrm{~b}$ \\
\hline AG 2005-E & $109.7 b$ & $69.1 b$ & $43.6 \mathrm{~b}$ & $35.1 b$ & $28.3 b$ & $50 \mathrm{~b}$ \\
\hline Qualimax & $78.5 \mathrm{c}$ & $51.9 \mathrm{c}$ & $38.5 b$ & $34.5 b$ & $30.6 b$ & $60 \mathrm{a}$ \\
\hline \multicolumn{7}{|c|}{ - } \\
\hline Volumax & $40.3 \mathrm{a}$ & $26.2 \mathrm{a}$ & $16.9 \mathrm{ab}$ & $14.1 \mathrm{ab}$ & $10.5 b$ & $48 b$ \\
\hline AG 2005-E & $32.5 b$ & $20.1 b$ & $13.0 \mathrm{~b}$ & $10.2 b$ & $7.1 \mathrm{~b}$ & $58 \mathrm{a}$ \\
\hline Qualimax & $42.7 \mathrm{a}$ & $28.1 \mathrm{a}$ & $20.5 \mathrm{a}$ & $17.0 \mathrm{a}$ & $15.2 \mathrm{a}$ & $59 a$ \\
\hline \multicolumn{7}{|c|}{ 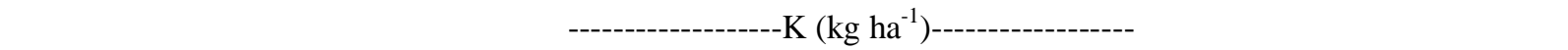 } \\
\hline Volumax & $182.6 b$ & $107.5 \mathrm{a}$ & $45.7 \mathrm{~b}$ & $19.2 b$ & $5.7 \mathrm{~b}$ & $32 \mathrm{a}$ \\
\hline AG 2005-E & $180.4 b$ & $101.3 \mathrm{a}$ & $40.3 b$ & $14.0 \mathrm{c}$ & $3.3 b$ & $31 \mathrm{a}$ \\
\hline Qualimax & $204.2 \mathrm{a}$ & $100.0 \mathrm{a}$ & $59.4 \mathrm{a}$ & $26.0 \mathrm{a}$ & $12.0 \mathrm{a}$ & $30 \mathrm{a}$ \\
\hline \multicolumn{7}{|c|}{ No till } \\
\hline DAM & 0 & 30 & 60 & 90 & 120 & $\mathrm{t}_{1 / 2 \text { (days) }}$ \\
\hline \multicolumn{7}{|c|}{---------------N $\left(\mathrm{kg} \mathrm{ha}^{-1}\right)---------------$} \\
\hline Volumax & $135.1 \mathrm{a}$ & $81.0 \mathrm{a}$ & $55.4 \mathrm{a}$ & $40.5 \mathrm{a}$ & $33.7 \mathrm{a}$ & $43 b$ \\
\hline AG 2005-E & $114.9 \mathrm{a}$ & $71.7 \mathrm{a}$ & $42.1 \mathrm{~b}$ & $33.9 \mathrm{a}$ & $23.5 b$ & $44 b$ \\
\hline Qualimax & $82.0 \mathrm{~b}$ & $55 . \mathrm{b}$ & $40.1 b$ & $31.1 \mathrm{a}$ & $22.0 \mathrm{~b}$ & $59 \mathrm{a}$ \\
\hline \multicolumn{7}{|c|}{  } \\
\hline Volumax & $42.9 \mathrm{a}$ & $26.2 \mathrm{a}$ & $17.6 \mathrm{a}$ & $15.1 \mathrm{a}$ & $12.7 \mathrm{a}$ & $35 b$ \\
\hline AG 2005-E & $30.3 b$ & $19.0 \mathrm{~b}$ & $11.8 \mathrm{~b}$ & $19.1 \mathrm{a}$ & $7.2 \mathrm{~b}$ & $45 \mathrm{a}$ \\
\hline Qualimax & $43.0 \mathrm{a}$ & $28.0 \mathrm{a}$ & $20.6 \mathrm{a}$ & $18.5 \mathrm{a}$ & $14.9 \mathrm{a}$ & $35 b$ \\
\hline \multicolumn{7}{|c|}{ 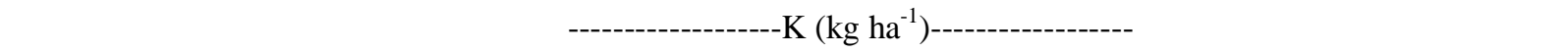 } \\
\hline Volumax & $187.6 \mathrm{~b}$ & $104.5 \mathrm{a}$ & $48.7 \mathrm{~b}$ & $24.2 b$ & $8.7 \mathrm{a}$ & $33 \mathrm{a}$ \\
\hline AG 2005-E & $183.4 \mathrm{~b}$ & $100.0 \mathrm{a}$ & $43.3 b$ & $20.0 \mathrm{~b}$ & $6.3 a$ & $34 a$ \\
\hline Qualimax & $200.2 \mathrm{a}$ & $107.0 \mathrm{a}$ & $62.1 \mathrm{a}$ & $31.0 \mathrm{a}$ & $9.0 \mathrm{a}$ & $29 a$ \\
\hline
\end{tabular}

Different letters on columns imply significant statistical difference by the Tukey test at $5 \%$ probability.

A hundred twenty days after management, the AG 2005-E hybrid presented the highest release rates compared to Qualimax and Volumax hybrids; this can be a relevant factor in the choice of this hybrid for use in soil coverage, since the quick release of the nutrients contained in the straw improves the biological and chemical conditions of the soil.

\section{CONCLUSIONS}

The straw from the sorghum hybrids AG 2005-E and Volumax presented quicker nutrient release to the soil than the Qualimax hybrid because the first two showed smaller $\mathrm{C} / \mathrm{N}$ ratios than the latter.
The biological attributes were susceptible to the changes in rainfall. The values of TOC, C-SMB, C-SMB/ TOC, basal respiration, and metabolic quotient $\left(q \mathrm{CO}_{2}\right)$ of the soil were greater during the rainy season when compared to the dry period.

\section{ACKNOWLEDGEMENTS}

The authors are grateful to the Brazilian National Council for Scientific and Technological Development $(\mathrm{CNPq})$ and the Brazilian Federal Agency for Support Evaluation of Graduate Education (CAPES) for funding the study. 


\section{REFERENCES}

ANDERSON, J.P.E.; DOMSCH, K.H. The metabolic quotient $\left(q \mathrm{CO}_{2}\right)$ as a specific activity parameter to assess the effects of environmental conditions, such as $\mathrm{pH}$, on the microbial biomass of forest soils. Soil Biology and Biochemistry, Oxford, v.25, p.393-395, 1993.

ARAÚJO, A.S.F.; SANTOS, B.B.; MONTEIRO, R.T.R. Responses of soil microbial biomass and activity for practices of organic and conventional farming systems in Piauí state, Brazil. European Journal of Soil Biology, Braunschweig, v.44, p.225-230, 2008.

BOER, C.A. et al. Ciclagem de nutrientes por plantas de cobertura na entressafra em um solo de cerrado.

Pesquisa Agropecuária Brasileira, Brasília, v.42, p.12691276, 2007.

CÂNDIDO, L.A. et al. O clima atual e futuro da Amazônia nos cenários do IPCC: A Questão da savanização.

Ciência e Cultura, Campinas, v.59, n.3, July/Sept., p.4447, 2007.

CARNEIRO, M.A.C. et al. Produção de fitomassa de diferentes espécies de cobertura e suas alterações na atividade microbiana de solo de Cerrado. Bragantia, Campinas, v.6, n.2, p.455-462, 2008.

CARNEIRO, M.A.C. et al. Atributos físicos, químicos e biológicos de solo de cerrado sob diferentes sistemas de uso e manejo. Revista Brasileira de Ciência do Solo, Viçosa, v.33, p.147-157, 2009.

ČERNÝ, J. et al. The changes in microbial biomass $\mathrm{C}$ and $\mathrm{N}$ in long-term field experiments. Plant, Soil and Environment, Prague, v.54, p.212-218, 2008.

EMPRESA BRASILEIRA DE PESQUISA AGROPECUÁRIA - EMBRAPA. Centro Nacional de Pesquisa de Solos. Manual de métodos de análise de solo. 2. ed. Rio de Janeiro, 1997. 212p.

EMPRESA BRASILEIRA DE PESQUISA AGROPECUÁRIA - EMBRAPA. Centro Nacional de Pesquisa de Solos. Sistema Brasileiro de Classificação de Solos. 2.ed. Rio de Janeiro, 2006. 306p.

FERREIRA, D. F. Sisvar: a computer statistical analysis system. Ciência e Agrotecnologia, Lavras, v.35, n.6, p.1039-1042, 2011.
FOLLET, R.F.; SCHIMEL, D.S. Effect of tillage practices on microbial biomass dynamics. Soil Science Society of America Journal., Madison, v.53, p.1091- 1096, 1989.

JENKINSON, D.S.; POWLSON, D.S. The effects of biocidal treatments on metabolism in soil - V: A method for measuring soil biomass. Soil Biology and Biochemistry, Oxford, v.8, n.3, p.209-213, 1976.

KASCHUC, G; ALBERTON O.; HUNGRIAM.

Quantifying effects of different agricultural land uses on soil microbial biomass and activity in Brazilian biomes: inferences to improve soil quality. Plant and Soil, Dordrecht, v.338, p.467-481, 2011.

MATEUS, G.P.; CRUSCIOL, C.A.C.; NEGRISOLI, E. Palhada do sorgo de guiné gigante no estabelecimento de plantas daninhas em área de plantio direto. Pesquisa Agropecuária Brasileira, Brasília, v.39, p.539-542, 2004.

METAY, A. et al. Storage and forms of organic carbon in a no-tillage under cover crops systems on clayey Oxisol in dryland rice productions (Cerrados, Brazil). Soil \& Tillage Research, Amsterdam, v.94, p.122-132, 2007.

NARDOTO, G.B.; BUSTAMANTE, M.M.C. Effects of fire on soil nitrogen dynamics and microbial biomass in savannas of central Brazil. Pesquisa Agropecuária Brasileira, Brasília, v.38, p.955-962, 2003.

PAUL, E.A.; CLARK, F.E. Dynamics of residue decomposition and soil organic matter turnover. In: Soil microbiology and biochemistry. $2^{\text {nd }}$ ed. San Diego: Academic, 1996. p.158-179.

PORTO, M.L. et al. Indicadores biológicos de qualidade do solo em diferentes sistemas de uso no brejo paraibano. Ciência e Agrotecnologia, Lavras, v.33, n.4, p.1011-1017, 2009.

RANGEL, O.J.P.; SILVA, C.A. Estoques de carbono e nitrogênio e frações orgânicas de Latossolo submetido a diferentes sistemas de uso e manejo. Revista Brasileira de Ciência do Solo, Viçosa, v.31, p.1609-1623, 2007.

SILVA, M.B. da; et al. Atributos biológicos do solo sob influência da cobertura vegetal e sistema de manejo.

Pesquisa Agropecuária Brasileira, Brasília, v.42, p.17551761, 2007. 
STOTT, D.E. et al. Wheat residue loss from fields under no-till management. Soil Science Society of America Journal, Madison, v.54, p.92-98, 1990.

\section{TEIXEIRA, M.B.; LOSS,A.; PEREIRA,M.G;}

PIMENTEL,C. Decomposição e liberação de nutrientes da parte aérea de plantas de milheto e sorgo. Revista Brasileira de Ciência do Solo, Viçosa, v.35, p.867-876, 2011.

TORRES, J.L.R.; PEREIRA, M.G. Dinâmica do potássio nos resíduos vegetais de plantas de cobertura no cerrado. Revista Brasileira de Ciência do Solo, Viçosa, v.32, p.1609-1618, 2008.

TORRES, J.L.R.; PEREIRA,M.G.; FABIAN,A,J. Produção de fitomassa por plantas de cobertura e mineralização de seus resíduos em plantio direto. Pesquisa Agropecuária Brasileira, Brasília, v.43, n.3, p.421-428, 2008.
VANCE, E.D.; BROOKES, P.C.; JENKINSON,D.S.An extraction method for measuring soil microbial biomass. Soil Biology and Biochemistry, Oxford, v.19, p.703-707, 1987.

WIEDER, R.K.; LANG, G.E. A critique of the analytical methods used in examining decomposition data obtained from litter bags. Ecology, Washington, v.63, n.6, p.16361642, 1982.

XAVIER, F.A.S. et al. Biomassa microbiana e matéria orgânica leve em solos na chapada da Ibiapaba-CE. Revista Brasileira de Ciência do Solo, Viçosa, v.30, p.247-258, 2006.

ZANG, J. et al. Effect of long-term application of manure and mineral fertilizers on nitrogen mineralization and microbial biomass in paddy soil during rice growth stages. Plant, Soil and Environment, Prague, v.55, p.101109, 2009. 